\title{
Chiara Minelli \\ Rationabilitas e codificazione canonica. Alla ricerca DI UN LINGUAGGIO CONDIVISO \\ G. Giapichelli Editore, Torino 2015, Ss. 210
}

W serii wydawanej przez Wydział Prawa Uniwersytetu w Brescii (Włochy) ukazała się monografia pt. Rationabilitas e codificazione canonica. Alla ricerca di un linguaggio condiviso (Racjonalność i kodyfikacja kanoniczna. W poszukiwaniu języka współdzielonego), autorstwa Chiary Minelli, która na tymże wydziale wykłada prawo wyznaniowe, prawo kanoniczne, w tym kanoniczne prawo małżeńskie materialne i procesowe. Pozycja ta poświęcona jest badaniom nad językiem stosowanym w ustawach kanonicznych, a w szczególności stosowania łacińskiego terminu rationabilitas („racjonalność", „rozumność") w kodyfikacjach prawa kanonicznego. W części wstępnej monografii autorka przywołuje konieczne doświadczenie historyczne. We wstępie zatytułowanym Dziedzictwo tradycji (L'eredità della tradizione) przytacza tezy św. Tomasza z Akwinu i Franciszka Suareza. Przede wszystkim przypomina tomaszową definicję prawa jako "ordinatio rationis", ale także kategorię racjonalności (rozumności) odnosi do oceny zwyczaju jako pozaustawowego źródła prawa (,'consuetudo est usus rationabilis"). W drugiej części wprowadzenia autorka omawia doświadczenie Kościoła w zakresie kodyfikacji prawa, które doprowadziło do sformułowania nowego Corpus Iuris Canonici za pontyfikatu papieża św. Jana Pawła II.

Zasadnicza część monografii została usystematyzowana w trzech rozdziałach, z których każdy dotyczy jednego kodeksu prawa kanonicznego dla Kościoła łacińskiego lub dla katolickich Kościołów wschodnich.

Rozdział I poświęcony został kodyfikacji pio-benedyktyńskiej, czyli Kodeksowi Prawa Kanonicznego promulgowanemu w 1917 r. (La codificazione piobenedettina). Autorka zajmuje się w nim w szczególności wpływem Soboru Watykańskiego I na prace zmierzające do reformy i kodyfikacji prawa kanonicznego w kontekście oczekiwania harmonijności przepisów. Następnie omawia rolę kanonistów w poszukiwaniu systemu „ra- 
cjonalnego". Zwraca przy tym uwagę na konieczność reformy i przejścia od "prawa abstrakcyjnego" do "prawa realnego". Z kolei przechodzi do omówienia kategorii podstawowych, zawartych w "prolegomena”, czyli we wstępnych rozważaniach wprowadzających do podstawowego zagadnienia, a dotyczących relacji lex i consuetudo w opiniach kanonistów i konsultorów komisji kodyfikacyjnej. Kolejny temat rozważań autorki stanowią normy ogólne jako zasady, które mają tworzyć ramy dla legislacji praktycznej i podmiotowej, zgodnie z zasadą wyrażoną przez św. Piusa X w motu proprio "Arduum sane munus”, aby w kodeksie uporządkować przepisy prawa kanonicznego zarówno odnośnie do materii, jak i w odniesieniu do jego formy. To papieskie wskazanie znalazło swoją realizacje m.in. $\mathrm{w}$ przepisach sformułowanych $\mathrm{w}$ nowym kodeksie, także tych odnoszących się do kwestii racjonalności (rozumności) argumentacji. Przede wszystkim odniesienia do kryterium racjonalności znajdują się $\mathrm{w}$ tematyce związanej z zagadnieniem ustaw kościelnych (de legibus ecclesiasticis), zauważając jednak rationabilitas zarówno w rozwoju sformułowań norm, jak i w argumentacji uzasadniającej przepisy, będącej mens legislatoris. W sposób wyraźny argument racjonalności pojawia się w dwóch obszarach. Pierwszym jest kwestia zwyczaju jako źródła prawa, zwłaszcza zwyczaju contra i praeter legem, który może stanowić źródło prawa jeśli „sit rationabilis”. Stąd też zwyczaj „irracjonalny” za takie źródło prawa uważany być nie może. To zagadnienie stało się tematem debat w komisji kodyfikacyjnej, co autorka skrupulatnie referuje. Efektem prac komisji było sformułowanie kanonów 27 i 28 Kodeksu Prawa Kanonicznego z 1917 r., w których prawodawca postanowił, że jedynie racjonalny zwyczaj obok prawa kościelnego stosowany rationabiliter przez 40 lat, a przeciwny prawu kościelnemu przez co najmniej sto lat staje się źródłem prawa, z zastrzeżeniem wykluczenia rationabilitatis, gdy był wyraźnie zabroniony przez ustawę.

Drugim miejscem, w którym argument „racjonalności” został w sposób wyraźny wspomniany są przepisy dotyczące dyspensy, a właściwie uzasadnienia dla jej zastosowania. Causa dispensandi, zgodnie z kan. 84 Kodeksu Prawa Kanonicznego z 1917 r. winna być m.in. racjonalna. Należy przy tym dodać, że autorka nie wskazuje na ponad 30 innych miejsc w tymże Kodeksie, odwołujących się wyraźnie do rationabilitatis.

Podobnie skonstruowany został przez autorkę rozdział II, zatytułowany Kodeks Prawa Kanonicznego z 1983 roku (Il Codex Iuris Canonici del 1983). Ch. Minelli omawia w nim najpierw zasady reformy posoborowej (po Vaticanum II), problemy metodologiczne i kryzys prawa kanonicznego, po czym przechodzi do omówienia prac nad reformą norm ogólnych, w tym 
zagadnienia promulgacji ustaw kościelnych i umieszczenia w tychże argumentu racjonalności. Przedstawia opinie konsultorów i innych organów odnoszące się tych zagadnień, które znalazły swoje zwieńczenie w pierwszej księdze nowego kodeksu w kan. 24 (zwyczaj) i 90 (dyspensa). Autorka konsekwentnie nie podejmuje i $\mathrm{w}$ tym rozdziale argumentu racjonalności w innych przepisach kodeksu (a jest ich kilkanaście).

Trzeci rozdział monografii jest zatytułowany Kodyfikacja prawa Kościotów wschodnich (La codificazione del diritto delle Chiese orientali). W dwóch pierwszych częściach tego rozdziału autorka prezentuje prace komisji kodyfikacyjnych zmierzających do sformułowania kodeksu, wskazując na roztropność (prudentia orientale) oraz łagodność (tranquilitas ordinis) jako klucze interpretacyjne. Samą kodyfikację posoborową umieszcza pomiędzy tradycją a innowacja po czym wskazuje jako kluczowe zasady: „dobro duchowe wiernych" oraz "słuszna i racjonalna przyczyna”. W tym kontekście autorka przytacza opinie konsultorów komisji kodyfikacyjnej oraz wyniki prac komisji w sprawie Lex Ecclesiae Fundamentalis. Także w tym rozdziale autorka konkluduje swoje rozważania odniesieniami do kwestii zwyczaju i przyczyn udzielenia dyspensy.

W zakończeniu zatytułowanym Rationabilitas. Język wspótdzielony (Rationabilitas. Il linguaggio condiviso) autorka streszcza wywody zawarte w trzech zasadniczych rozdziałach monografii i wskazuje na walor prawny i kulturowy rationabilitatis $\mathrm{w}$ argumentacji kanoniczno-prawnej.

Monografia stanowi interesujący przyczynek do badań nad językiem kanoniczno-prawnym, a także do badań nad historią kodyfikacji kanonicznych XX w.

rec. Leszek Adamowicz*

* Dr hab., prof. Katolickiego Uniwersytetu Lubelskiego Jana Pawła II; e-mail: adleszek@kul.pl 